\title{
Does Early Childhood Teacher Education Affect Students' Cognitive Orientations?
}

\section{The Effect of Different Education Tracks in Teacher Education on Prospective Early Childhood Teachers' Cognitive Orientations in Germany}

\author{
Christoph Mischo, Stefan Wahl, Janina Strohmer \& Carina Wolf \\ Department of Psychology, University of Education, Freiburg, Germany \\ Correspondence: Christoph Mischo, Department of Psychology, University of Education, Kunzenweg 21, 79117 \\ Freiburg, Germany.
}

\author{
Received: August 20, 2013 Accepted: September 8, 2013 Online Published: November 11, 2013 \\ doi:10.11114/jets.v2i1.206 URL: http://dx.doi.org/10.11114/jets.v2i1.206
}

\begin{abstract}
Early childhood teachers may differ regarding the knowledge base they use when making professional decisions. In this study two orientations are distinguished: the orientation towards scientific knowledge vs. the orientation towards intuition and subjective experience. As different tracks in early childhood teacher education qualify for professional practice, and as education of early childhood teachers matters with regard to developmental outcomes of children, knowledge orientations of prospective early childhood teachers attending universities and attending vocational schools are investigated and compared. Knowledge orientations were assessed by means of a questionnaire. After propensity score matching of 402 beginners and 402 graduates, multilevel analyses indicate that scientific orientation at the end of teacher education was higher and subjective orientation was lower than at the beginning. Furthermore, scientific knowledge orientation of BA-students was higher, subjective orientation was lower than of students at professional schools. Implications of these results regarding education of early childhood teachers are discussed.
\end{abstract}

Keywords: cognitive orientations, epistemological beliefs, early childhood teacher, teacher education

\section{Introduction}

\subsection{Knowledge Orientations as Relevant Aspects of Orientation Quality}

Which knowledge early childhood teachers rely on when they make decisions is a question of theoretical and practical importance (Hedges, 2012). Early childhood educators may rely on their own intuition and on "personal practical knowledge" in everyday practice (Spodek, 1987; Hedges, 2012). This personal knowledge may be tacit, implicit (Loughran, Mitchell \& Mitchell, 2003) and informal (Hedges, 2012).

On the other hand it is often claimed that teaching practice should be research based (Glaser \& Takanishi, 1986; Wang, Haertel \& Walberg, 1993; Penn \& Lloyd, 2007). Regarding early childhood teacher education in the US the term "evidence based practice" has been employed in order to emphasize that "all professional development should be (...) consistent with the principles of adult learning and structured to promote linkages between research, theory, and practice" (NAECY \& NACCRRA, 2011, p. 5). As Buysse, Wesley, Snyder \& Winton (2006) point out, the term "evidence-based practice" means "a decision-making process that integrates the best available research evidence with family and professional wisdom and values." In contrast to evidence based practice, the authors quote rules of thumb, folklore, and tradition (Buysse \& Wesley, 2006; National Registry of Evidence Based Practices and Programs NREPP, 2007). These authors recommend that (a) practitioners should be supplied with accessible research-based information, (b) should become critical consumers of research, (c) should be able to integrate research evidence with practical wisdom, and (d) should apply this information for making decisions according to the needs and priorities of children and families (see also Buysse, Winton, Rous, Epstein \& Lim, 2012). Many other authors have also highlighted the relevance of reliable scientific knowledge for professional practice in teaching and early childhood education (Bredekamp, 
1988, 1995; Hiebert, Gallimore \& Stigler, 2002; Garbett, 2003; Hyson, Tomlinson \& Morris, 2009; Shulman, 1986; Silin, 1987). Other researchers have doubted that teaching can be evidence-based and rather prefer the term "evidence-informed" (Hammersley, 2005; Hedges, 2012).

As education of early childhood teachers is an important factor of early childhood settings (Kelley \& Camilli, 2007; Saracho \& Spodek, 2007), the question arises whether early childhood teacher education affects the knowledge base early childhood teacher students rely on.

The term "knowledge orientation" used in this study shows significant overlap to the terms "personal epistemology" and "epistemological beliefs" which refer to beliefs about knowledge and knowing (e.g. Buehl \& Alexander, 2001; Hofer, 2001). Therefore we sketch briefly the existing results about personal epistemologies.

\subsection{What Do We Already Know about Personal Epistemologies?}

Personal epistemologies are individual views about knowledge and may affect the individual's learning and learning outcome and have an impact on pedagogical practice (Brownlee \& Berthelsen, 2005; Buehl \& Alexander, 2001; Hofer, 2001; Rodriguez \& Cano, 2006; Schommer, 1990). Furthermore, personal epistemologies are connected to larger cognitive and affective systems, which include beliefs about knowledge, beliefs about knowing, and beliefs about self-regulated learning (Schommer-Aikens, 2004). Epistemological beliefs are related to the age of the belief holder, to other personal characteristics (such as cognitive abilities), the subject being considered (e.g., "hard" subjects such as physics versus "soft" subjects such as psychology) and the social context (Hofer, 2001; Lodewyk, 2007; Schommer, 1994).

Hofer (2001) proposed the dimensions "certainty of knowledge", "source of knowledge", "justification" and "simplicity" in order to describe relevant aspects in which personal epistemologies can differ.

The classical study of Perry (1970) described the progress of students' epistemological beliefs from a dualistic position (viewing knowledge as simple, certain, and taught by authorities) to a relativistic position viewing knowledge as actively constructed and evaluated (see also Brownlee \& Berthelsen, 2005; Walker, Brownlee, Whiteford, Exely \& Woods, 2012). Other data as well suggest that beliefs can vary as a function of grade level in education (Vartuli, 1999) or as a function of time (Vartuli and Rohs, 2009; Walker, Brownlee, Whiteford, Exely \& Woods, 2012).

\subsection{Focus of the Present Study}

Turning back to the concept of evidence-based practice, the focus of the present study lies on early childhood teachers' orientations towards science and scientific knowledge in contrast to their subjective intuition. These types of knowledge orientations refer to different orientations which have been discussed in early childhood research: scientific knowledge, critical thinking (Yost, Sentner \& Forlenza, Baily, 2000) on the one hand and intuition, practical knowledge (Cervero, 1990), pseudo-scientific knowledge (Kallery, 2001), or intuition on the other hand. However, some authors question the distinction between "practical knowledge" and "theoretical knowledge" (Russell, 1987; Fenstermacher, 1994).

We prefer the terms "subjective theories" versus "objective theories" (Groeben, Wahl, Schlee \& Scheele, 1988; Groeben, 1990): "subjective theories" refer to subjective beliefs and belief-systems, subjective convictions and lay theories (Schmid \& Lutz, 2007), implicit theories (Dweck, Chiu \& Hong, 1995), common sense and practical wisdom (Buchmann, 1984). According to Belenky, Clinchy, Goldberger \& Tarule (1986) subjective theories ("subjective knowing") are based rather on private and personal experience, intuition and feeling than on well-defined ideas (Buehl \& Alexander, 2001). In contrast, the term "objective theories" refers to scientific theories that are based on (comparatively) precise concepts and empirically validation (Groeben, 1990).

This understanding of the terms "objective" versus "subjective theories" matches with the "scientific orientation" versus "clinical orientation" proposed by Freidson (1970) and applied by Katz $(1987,1993)$ to the field of early childhood teacher education. As Katz (1993) argues, scientists in the field of medicine exhibit reflective, theoretical and sceptical thinking. Practitioners in this field, however, rely on pragmatic, subjective orientation, faith and indeterminacy. Katz (1987) transferred this distinction to early childhood professionals and proposed that scholars and practitioners in early childhood education are members of two different subcultures with their own orientations, habits and language. Katz (1993) assumes that people who train practitioners in early childhood education may be thought of a third group "between" scientists and practitioners. In preferring the terms "objective theories" and "subjective theories" instead of "scientific orientation" and "clinical orientation" we modified the distinction of Katz (1993) according to the two dimensions of knowledge orientations outlined in table 1. 
Table 1. Orientations towards knowledge adapted and modified from Katz (1993).

\begin{tabular}{ll}
\hline & The two dimensions of cognitive orientations \\
\hline $\begin{array}{l}\text { Orientation towards } \\
\text { objective theories }\end{array}$ & $\begin{array}{l}\text { Orientation towards } \\
\text { subjective theories }\end{array}$ \\
\hline 1. reflective & 1. active \\
2. conceptual & 2. pragmatic \\
3. theoretical & 3. subjective \\
4. skepticism & 4. faith \\
5. empirical research & 5. own experience \\
\hline
\end{tabular}

The distinction between a objective (scientific) vs. subjective theory orientation does not necessarily affect the quality of personal epistemologies proposed e.g. by Perry (1970), Brownlee and Berthelsen (2005), Hofer and Pintrich (1997), and others. Irrespective of the beliefs about the "nature of knowledge" and the "nature of knowing" (Hofer \& Pintrich, 1997), a knowledge orientation towards objective (scientific) theories means that scientific theories and empirical results are considered, whereas an orientation towards subjective theories indicates that the belief holder primarily relies on his own experiences and subjective beliefs.

In a previous study, the existence of difference knowledge orientations based on the distinction of Katz (1987; 1993) in prospective early childhood teachers could be shown. By means of a latent profile analysis, beliefs of 712 prospective early childhood teachers at their fourth semester in early childhood teacher education in Germany could be classified as "orientation towards objective theories" and "subjective theories" (Mischo, Wahl, Strohmer \& Hendler, (2012). Hence, these knowledge orientations that are based on the distinction of Freidson (1970) and Katz (1993) were empirically supported. In contrast to the model of Freidson and Katz, the attributes in the study of Mischo et al. (2012) were not conceptualized as opposite poles of the same dimensions (and thereby mutually exclusive) but as different attributes presented in a questionnaire. Presenting these attributes (e.g. reflective, active, conceptual, pragmatic, see table 1) as different (and not as mutually exclusive) attributes implicates that individual may have high scores on the attribute reflective and high scores on the attribute active etc. This conceptualization better fits to an approach of evidence-based practice, as one would expect that "good" professionals show a reflective and an active orientation, think conceptually and pragmatically, deliberate on a theoretical level and, in concrete interactions with a child, act according to their subjective attitudes and beliefs (see also Brownlee \& Berthelsen, 2005). By conceptualizing these two prototypical knowledge orientations not as opposite poles but as two distinct dimensions, the correlation between these two dimensions is empirically testable. The unfolding of these two dimensions makes it possible to describe a certain knowledge orientation on each of the two dimensions. In fact, the results of the latent profile analyses of Mischo et al. (2012) yielded that even individuals with an "subjective orientation" had raw scores on items indicating a scientific orientation above the theoretical mean, and raw means indicating a subjective orientation were mainly between the value 2 (rather disagree) and 3 (rather agree) for both cognitive orientation profiles, which means that even members of the scientific orientation profile did not completely disclaim a subjective theory orientation. Insofar these results suggest a certain degree of accounting for both orientations in prospective early childhood teachers "in the middle" of their early childhood teacher education (fourth semester; for details see Mischo, Wahl, Strohmer \& Hendler, 2012). Hence, the orientation profiles identified in the study of Mischo et al. characterize only a relative difference in cognitive orientations.

Whereas in the study of Mischo et al. a person-centered approach was realized in order to identify orientation profiles and classes of persons associated with these profiles, the question remains whether cognitive orientations are affected by early childhood teacher education. In particular, there exists no empirical research whether early childhood teacher education foster the development of a scientific orientation as preached by the evidence based practice-approach. This question suggests not a person-centered but a variable centered approach (Laursen \& Hoff, 2003).

\subsection{Effect of Academic Level in Early Childhood Teacher Education}

In Germany as well as in other countries, there exists no single track and no single level of qualification in early childhood education (Oberhuemer, Schreyer \& Neumann, 2010; see also Morgan, 2003). More than two thirds of the early childhood staff in Germany completes a three-year course of study at a post-secondary vocational school specializing in social pedagogy, which leads to a credential as a state registered educational professional. However, the percentage of staff in Germany with an academic qualification level (Bachelor's degree) is very low (about 3 percent; Oberhuemer, Schreyer \& Neumann, 2010). In the German system, if applicants had graduated from general education school (A-Level in UK), they can choose between the academic track of early 
childhood education (bachelor's degree) or the vocational professional school which requires at least an O-level. In both cases, most early childhood teacher education programs take three years.

There exists empirical evidence that a higher level of teacher education is associated with higher levels quality outcomes (Kelley \& Camilli, 2007; NICHD Early Childhood Research Network, 2002; 2003; Pianta, Howes, Burchinal, Bryant, Clifford, Early \& Barbarin, 2005; Whitebook, 2003). It seems plausible that early childhood teacher education fosters the quality of early childhood professionals' cognitive orientations (Biggs, 1993; Snider $\& \mathrm{Fu}, 1990)$. However, the attending of university level courses should not be regarded as sufficient for higher institutional quality (Early et al., 2007; Zaslow et al., 2010).

With regard to knowledge orientations, it may be expected that prospective early childhood teachers with an academic education to a higher degree acquire a scientific orientation as themes such as research and research methods are only part of the qualifications framework for an education on bachelor's level, not part of the qualifications framework for vocational schools in Germany (Bosch-Stiftung, 2008). However, these qualifications framework in Germany have been formulated by early childhood experts but are not obligatory, neither for universities nor for vocational schools. According to the claims of the OECD (2004) the academization of early childhood teacher education in Germany is expected to lead to a higher level of professionalization and also to a broader dissemination of scientific orientations (for Finnland see Kinos \& Virtanen, 2008).

In fact, in the study of Mischo, Wahl, Strohmer and Hendler (2012), bachelor students were to a higher degree represented in the scientific orientation profile whereas comparatively more vocational students belonged to the subjective orientation profile. However, the data in the study of Mischo et al. were assessed at prospective early childhood teachers at their fourth semester of early childhood teacher education. Thus, it cannot be differentiated whether the difference in cognitive orientations between prospective teachers of different academic levels already existed at the beginning of teacher education (e.g. as a result of a selection bias) or were due to an effect of the education and socialization in the different education tracks. In order to differentiate between a potential selection bias-effect versus a true effect of teacher education data from prospective early childhood teachers at the beginning and at the end of teacher education should be taken into account. The research questions of the present study are outlined in the following.

\subsection{Research Questions/Hypotheses}

\section{Research question 1: Overall change of knowledge orientations}

Do knowledge orientations (scientific orientation, subjective orientation) change from the beginning to the end of early childhood teacher education?

\section{Research question 2: Differential change in different academic tracks of early childhood teacher education}

Are there differential changes regarding different academic levels of teacher education?

Taking the claim of academization of early childhood teacher education seriously, this research question can be concretized as follows:

It can be hypothesized that the increase of BA-level students' orientation towards objective theories is higher than the increase of corresponding orientations of vocational school students.

\section{Research question 3: Selection bias of different academic tracks of early childhood teacher education}

Do knowledge orientations of prospective early childhood educators of different education tracks already differ at the beginning of teacher education?

\section{Additional research question (difference at the end of education)}

In addition, it will be of interest whether knowledge orientations between members of different academic tracks differ at the end of early childhood teacher education. This question, however, is not completely independent from research questions (2) und (3), as it is not very likely that graduates of different academic tracks differ at the end of their education if no differential development of knowledge orientations (research question 2) and/or no selection bias (research question 3) could be confirmed. In addition, we analysed whether differences between institutions of the same track exist. This analysis addresses the question whether the variability in concrete profiles of institutions affects variability in cognitive orientations within each track.

\section{Method}

\subsection{Sample and Participants}

As could be expected, mean age of university students was higher than of students at vocational schools 
(beginners: mean age at vocational schools $=20.54, \mathrm{SD}=4.06$, at universities $=22.49, \mathrm{SD}=4.69$; graduates: mean age at vocational schools $=23.95, \mathrm{SD}=4.31$, mean age at universities $=24.65, \mathrm{SD}=4.40$ ).

\subsection{Measures}

\subsubsection{Assessment of Knowledge Orientation}

A questionnaire including statements which indicate an orientation to objective theories (scientific orientation) and an orientation to subjective theories was constructed. The rationale for the item construction was the description of Katz (1993; see table 1), which was slightly modified. A pre-version of items were given to experts in the field of early childhood education. After incorporating comments of experts in the item formulations a final version of the questionnaire was developed. Statements in the questionnaire were not ordered according to the corresponding knowledge orientations. Participants were asked to rate their agreement with each of the statements on a four point rating scale (from 1 = "I do not agree" to 4 = "I agree"). Some of the items were negatively poled and were recoded.

Item examples may enlighten how the attributes characterizing an orientation towards objective theories (see table 1) were operationalized: reflective: "A critical understanding of theories of early childhood education is necessary in order to reflect the own work" (see item 8, table 2), conceptual: "In order to evaluate a child's language development, the early childhood teacher should know concepts about language development and specific language impairments" (item 2, table 2), theoretical: "Without knowledge about theories of language development early childhood teachers cannot really promote language development" (item 3, table 2), scepticism: "If scientific studies yield that an educational concept is not effective, I don't act upon this concept" (item 18, table 2), empirical research: "It is important that training programs in early childhood education are scientifically evaluated" (item 14, table 2).

The following items are examples for attributes indicating an orientation to subjective theories (see table 1): active: "Insight for good action may be primarily drawn from one's own and others' experience" (item 21, table 2), pragmatic: "Whether a training program is effective is indicated by the practical experiences of the early childhood teachers, participants and parents" (item 15, table 2), subjective: "I master difficult situations best when I follow my subjective intuition" (item 5, table 2), faith: "A really good early childhood teacher should trust her own instinct" (item 7, table 2), own experience: "In order to promote language development, it is crucial than an early childhood teacher trusts his/her own experience" (item 6, table 2).

In order to construct a reliable scale items had to be deleted from the total scale. The resulting scale "orientation towards objective theories" consisted of 13 items, the scale "orientation towards subjective theories" of 8 items. The resulting items are presented in table 2 .

Table 2. Questionnaire assessing knowledge orientations.

\section{Item}

$1 \quad$ Educational theories are not important for my acting as early childhood teacher (recoded).

2 In order to evaluate a child's language development, the early childhood teacher should know concepts about language development and specific language impairments.

3 Without knowledge about theories of language development, early childhood teachers can not really promote language development.

$4 \quad$ I master difficult situations best when I follow my subjective intuition.

5 Theories of early childhood are too abstract in order to deduce solutions for problematic situations in early childhood education and care (recoded).

6 In order to promote language development, it is crucial than an early childhood teacher trusts his/her own experience.

$7 \quad$ A really good early childhood teacher should trust his/her own instinct.

8 A critical understanding of early childhood theories is necessary in order to reflect the own work.

9 The most important qualification of an early childhood teacher is his/her personal experience in early childhood settings.

10 In order to evaluate work in early childhood settings, the subjective impressions of the professionals are of primary importance.

11 In order to evaluate professional work in early childhood settings, procedures and instruments of quality management are indispensable.

12 In order to assess a child's development, the application of observational records is necessary. 
13 In order to assess learning and development, it is sufficient if early childhood teachers use their own impressions and statements of parents or colleagues.

14 It is import that training programs in early childhood education are scientifically evaluated.

15 Whether a training program is effective is indicated by the practical experiences of the early childhood teachers, participants and parents.

16 In order to evaluate the effect of an intervention program, a scientific investigation is dispensable (recoded).

17 In order to evaluation effectiveness of an intervention program it is not sufficient to ask early childhood teachers, children and parents about their experiences with the program (recoded).

18 If scientific studies yield that an educational concept is not effective I don't act upon this concept.

19 Important conclusions for early childhood teachers can be drawn from studies in early childhood education.

20 As every situation is different in early childhood settings scientific results are not helpful for the concrete work with children (recoded).

21 Insight for good action may be primarily drawn from one's own and others' experience.

Note. Orientation towards objective theories: items 1, 2, 3, 5, 8, 11, 12, 14, 16, 17, 18, 19, 20; orientation towards subjective theories: items $4,6,7,9,10,13,15,21$.

For beginners (first semester) Cronbach's $\alpha$ for the scale "orientation towards objective theories" was .69, for the scale "orientation towards subjective theories" .61. Both scales were modestly negatively correlated $(\mathrm{r}=-.27, p$ $<.001)$.

For graduates (sixth/seventh semester) reliability for the scale "orientation towards objective theories" was $\alpha$ $=.77$ (13 items), for the scale "orientation towards subjective theories" .71 (8 items). For graduates as well, both scales were negatively correlated $(\mathrm{r}=-.39, p<.001)$. These correlations suggest that, especially at the beginning of teacher education, these two scales assess slightly antithetic constructs, but are not just opposite characteristics of the same constructs.

\subsubsection{Assessment of Background Variables}

The study presented in this article is part of a larger study about professionalization of prospective early childhood teachers. In this larger study a variety of background variables and competence measures was assessed. However, not all background variables were assessed at the beginning of early childhood teacher education. For purpose of clarity, only those variables are reported that were assessed in both cohorts and are used in the present analysis.

Besides sex and age, background variables which might affect knowledge orientations and/or belonging to the cohort of beginners vs. cohort of graduates were taken into account. In previous studies, it could be shown that e.g. the degree of subjective confidence of the career choice to work in early childhood centers affected motivational goal orientation (and potentially cognitive orientation) during early childhood teacher education (Mischo, Wahl, Hendler \& Strohmer, 2012). The subjective confidence of the career choice itself is correlated with a variety of attributes, e.g. awareness of decision and the tendency to replicate the decision. Hence, the following background variables (besides age and sex) were assessed: previous experiences in early childhood settings (dichotomous: yes vs. no), subjective awareness of decision (dichotomous: aware vs. not aware), subjective confidence (four-point rating scale from not convinced to convinced), and the tendency to replicate the decision (yes vs. no).

\subsubsection{Data Analysis}

Matching of graduates and beginners

As available data resulted not from one follow up-design but from two cross cohort-studies (cross sectional study) of beginners and graduates, special measures of precaution have to be considered in order to ensure for comparability of the two cohorts. One powerful method to estimate unbiased treatment effect (e.g. the effect of the treatment "early childhood teacher education") is propensity score matching. Propensity score matching is a method to adjust a treatment effect (e.g. education effect) for measured confounders in a quasi-experiment (Rosenbaum \& Rubin, 1983). In propensity score matching, the predicted probability (propensity score) for each individual to the membership of the groups (cohort of graduates vs. cohort of beginners) based on certain covariates is calculated by logistic regression with covariates (e.g. sex, biographic variables) as predictors of group membership. The propensity scores exhibits how likely it is that a person falls into a certain group (e. g. a treatment group) given the observed values of covariates. For each member of the treatment condition (here: for each of the 577 graduates) one member of the control condition (here: from the total of 956 beginners) with a 
propensity score as equal as possible is selected (criterion of nearest neighbor-similarity). By this matching procedure a balance in propensity scores between participants of treatment and control (graduates and beginners) is achieved and a balance on the covariates used to calculate propensity scores between the two groups (cohorts) is accomplished (Stuart, 2010). Propensity score matching has certain advantages over covariance analysis (Tracz, Nelson, Newman \& Beltran, 2005; see also Hughes, Chen, Thoemmes \& Kwok, 2010).

For the present study all of the background variables described above besides age was taken as covariates in the logistic regression of the matching procedure. The age variable was not considered as it is inevitable (thus trivial) that the cohort of graduates differs from the cohort of beginners. The covariates used in logistic regression were sex, prior experience in early childhood centers, awareness of career choice, confidence of career choice, and the tendency to replicate the career choice. For the resulting propensity scores a caliper of maximum .02 for the standard deviation of propensity scores' logits was accepted. That means that for each member of the graduate cohort one member of the beginners' cohort was matched that had a maximum divergence of one fifth (.02) of the standard deviation of the logits of all propensity scores. This criterion ensures that the resulting matched pairs were as equal as possible. Altogether 402 members of the 956 beginners' cohort could be matched to 402 members of the graduates' cohort. In other words: the data of matched paired consisted of 804 participants. In the matched pairs data, 194 participants of the beginners' cohort $(\mathrm{N}=402)$ were students at universities and 208 were students at vocational schools, from the 402 participants at the end of their education, 193 were students at universities and 209 were students at vocational schools (48\% students at universities, $51 \%$ students at vocational schools).

Regarding propensity scores, the overall balance test of Hansen and Bowers (2008) was not significant $\left(\chi^{2}=0.36\right.$, $\mathrm{df}=5, p=.99$ ). The multivariate imbalance measure considerably decreased from .18 before matching to .08 after matching (see Iacus, King \& Porro, 2011). The visual inspection of standardized differences in propensity scores as well indicated a very good result of the matching procedure. In summary, the matching procedure led to matched pairs of graduates and beginners who were very similar regarding the set of covariates considered. These matched pairs-data were used for testing the hypotheses.

\section{Multilevel structure of data}

The present data have a multilevel structure (Bryk \& Raudenbush, 1992). Data from each participant of the study are located on level 1 and are nested within level 2 - units (one of the 30 institutions: vocational school or university). The type of institution (academic level: university vs. vocational school) constitutes a level 2 covariate (between group-predictor). Within each level 2 - unit (institution) there exist members of the beginners' cohorts and members of the graduates' cohort. Therefore the time of early childhood teacher education (beginning vs. end) is a level 1 - covariate (within group-predictor).

\section{Results}

\subsection{Descriptive Statistics of Knowledge Orientation Scales}

Means and standard deviations of the two scales for beginners and graduates (matched pairs) are presented in table 3 .

Table 3. Means and standard deviations (SD) for the two scales of cognitive orientations (matched pairs data).

\begin{tabular}{|c|c|c|c|c|}
\hline \multirow[t]{3}{*}{ Type of institution (track) } & \multicolumn{4}{|c|}{$\begin{array}{c}\text { Means (SD) for cognitive orientations } \\
\text { Time of assessment }\end{array}$} \\
\hline & \multicolumn{2}{|c|}{$\begin{array}{l}\text { Beginning of education } \\
\left(1^{\text {st }} \text { semester, } \mathrm{N}=402\right)\end{array}$} & \multicolumn{2}{|c|}{$\begin{array}{c}\text { End of education } \\
\left(6^{\text {th }} 7^{\text {th }} \text { semester, } N=402\right)\end{array}$} \\
\hline & $\begin{array}{c}\text { Subjective } \\
\text { theories }\end{array}$ & $\begin{array}{l}\text { Objective } \\
\text { theories }\end{array}$ & $\begin{array}{c}\text { Subjective } \\
\text { theories }\end{array}$ & $\begin{array}{c}\text { Objective } \\
\text { theories }\end{array}$ \\
\hline Vocational School (N = 378) & $2.93(0.40)$ & $2.94(0.35)$ & $2.76(0.41)$ & $2.99(0.36)$ \\
\hline University (BA-level; $\mathrm{N}=(417)$ & $2.72(0.41)$ & $3.09(0.32)$ & $2.49(0.40)$ & $3.24(0.35)$ \\
\hline
\end{tabular}

Note. Subjective theories: orientation towards subjective theories, Objective theories: orientation towards objective theories.

A visualization of the mean scores is depicted in figure 1. 


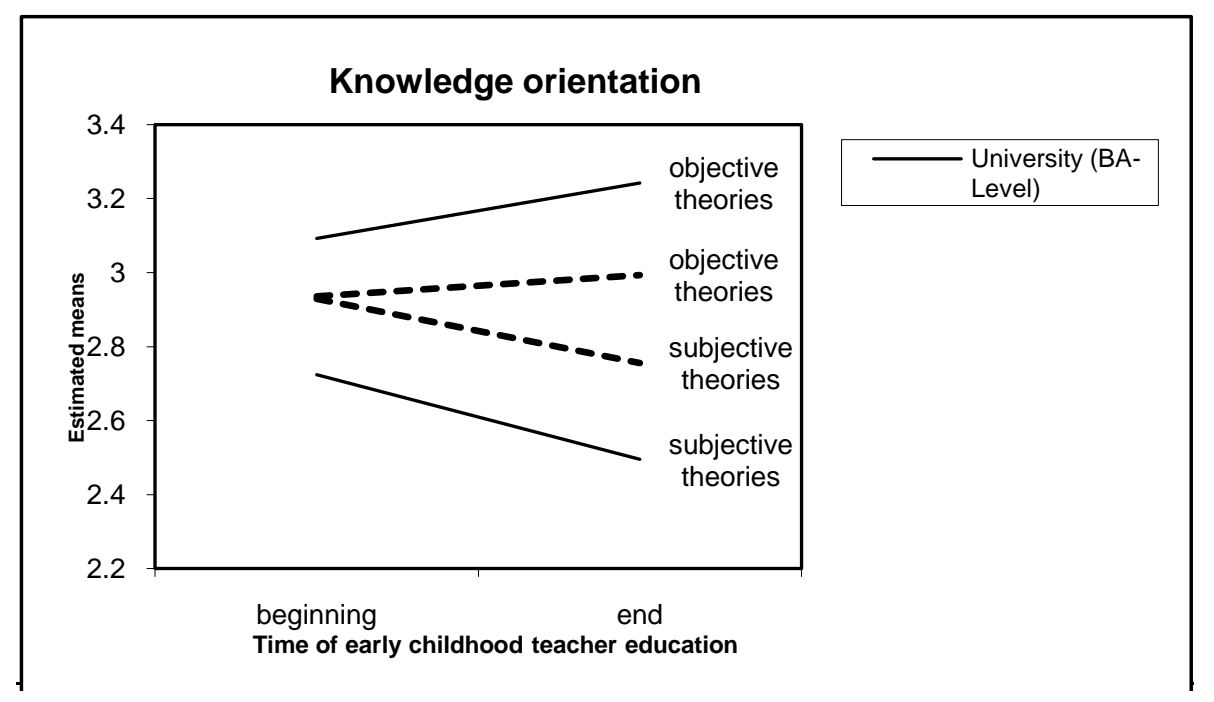

Figure 1. Plot of means for scales of cognitive orientations.

\subsection{Results according to Research Questions}

On individual level (level 1), time (beginning vs. end) was used as within group-predictor in a random slope multilevel model. On between level (level 2), type of institution (university vs. vocational school) was used as between group-predictor. Cross level-interaction was also considered by specifying type of institution as predictor for the random regression slope of the time effect. The total number of groups (institutions) was 30 (average group size $=14.3$ ). Dependent variables were scores for subjective and for objective orientations.

Intraclass correlation for the scale subjective orientation was .10, for the objective orientation scale .12 . That means that 10 percent of the variance of the subjective theory-scale was observed between groups (between institutions), 12 percent of the objective orientation scale's variance appeared between groups (between institutions). This part of variance was regressed on level 2-predictors (education track). The results of multilevel analyses are summarized in table 4 .

Table 4. Results of multilevel regression (matched pairs data, $\mathrm{N}=804$ ).

\begin{tabular}{|c|c|c|c|}
\hline $\begin{array}{l}\text { Dependent variable } \\
\text { Orientation towards }\end{array}$ & Predictor & B & SE (B) \\
\hline \multirow[t]{2}{*}{ subjective theories } & Time (for track = university) & $-0.06 * *$ & 0.02 \\
\hline & Type of institution (track) ${ }^{\mathrm{a}}$ & $0.19 * *$ & 0.05 \\
\hline $\begin{array}{l}\text { Effect of predictor time } \\
\text { cross level-interaction }\end{array}$ & $\begin{array}{l}\text { Track (increase of time-effect for } \\
\text { track = vocational school compared } \\
\text { to university) }\end{array}$ & 0.01 & 0.01 \\
\hline \multirow[t]{2}{*}{ objective theories } & Time $($ for track $=$ university $)$ & $0.05^{*}$ & 0.02 \\
\hline & Type of institution (track) ${ }^{\mathrm{a}}$ & $-0.13 * *$ & 0.05 \\
\hline $\begin{array}{l}\text { Effect of predictor time } \\
\text { cross level-interaction }\end{array}$ & $\begin{array}{l}\text { Track (increase of time-effect for } \\
\text { track = vocational school } \\
\text { compared to university) }\end{array}$ & $-0.02 \#$ & 0.01 \\
\hline
\end{tabular}

Research question 1 (overall change in knowledge orientations) is tested by the time-effect in the multilevel model. For orientation towards subjective theories, the effect of time was highly significant with a negative beta weight (beta $=-0.06$ ) which indicates a decrease of a subjective orientation (as could be seen in figure 1). The increase of scientific orientation was also significant with a positive beta weight (beta $=0.05$ ). Hence, the assumption of an overall change in knowledge orientations could be confirmed.

For both orientations, results revealed overall differences between types of institutions (tracks): a higher orientation towards subjective theories in vocational schools and a higher orientation towards objective theories 
in universities. The two knowledge orientation may also be at least partly confounded with the two access paths, the graduation on O-level for vocational schools, the A-level, matura, or international baccalaureate for universities.

\section{Research Question 2}

Regarding research question 2 (differential change), no differences in change of subjective orientation between vocational schools and universities appeared. For change in scientific orientation, only a tendency of statistical difference between universities and vocational schools could be detected $(p<.10)$ indicating that the increase in scientific orientation at vocational schools is slightly lower than increase in universities. For subjective orientation, the assumption of a differential change between tracks could not be confirmed, for scientific orientation, a differential change could only partly be confirmed as statistical tendency.

\section{Research Question 3}

Research question 3 (selection bias) was tested by analyzing only data for beginners. Multilevel regressions were performed using type of institution as predictor. For both cognitive orientation scales, about 9 percent for the variance appeared between institutions, (intraclass correlation $=.09$ ). Results are summarized in table 5 .

Table 5. Results of multilevel regression - beginning of teacher education $(\mathrm{N}=402)$.

\begin{tabular}{lllll}
\hline $\begin{array}{l}\text { Dependent variable } \\
\text { Orientation towards }\end{array}$ & & Predictor & $\mathrm{B}$ & $\mathrm{SE}(\mathrm{B})$ \\
\hline subjective theories & between & Type of institution (track) & & \\
\hline objective theories & between & Type of institution (track) & $-0.21^{* * *}$ & 0.05 \\
\hline
\end{tabular}

Note. B regression weight beta, SE (B) standard error of beta, $* * * p<.001,{ }^{\mathrm{a}} 1=$ university, $2=$ vocational school.

As for both cognitive orientations, the effect of the type of institution was highly significant a selection effect seems highly plausible. Prospective early childhood teachers with a higher orientation towards subjective theories tend to visit vocational schools whereas students with a higher orientation towards objective theories took the university track.

\section{Additional Research Question (difference at the end of education)}

When only data at the end of teacher education are considered, differences between different tracks remain highly significant (see table 6).

Table 6. Results of multilevel regression - end of teacher education $(\mathrm{N}=402)$.

\begin{tabular}{lllll}
\hline $\begin{array}{l}\text { Dependent variable } \\
\text { Orientation towards }\end{array}$ & Predictor & B & SE (B) \\
\hline subjective theories & between & Type of institution (track) & $0.25^{* * * *}$ & 0.07 \\
\hline objective theories & between & Type of institution (track) & $-0.24^{* * * *}$ & 0.06 \\
\hline
\end{tabular}

Note. B regression weight beta, SE (B) standard error of beta, ${ }^{* * *} \mathrm{p}<.001,{ }^{\mathrm{a}} 1=$ university, $2=$ vocational school.

Differences between institutions within each track of education were tested by calculating the design effect within each track. The design effect is a function of the intraclass correlation but takes the average cluster size into account. As a rule of thumb, design effects $>2$ are considered as substantial (Muthén, 2010). For reasons of comparison, design effects within each track were also calculated for the beginners' data (see table 7).

Table 7. Design effects within type of institution.

\begin{tabular}{|c|c|c|c|c|}
\hline \multirow[t]{3}{*}{ Type of institution (track) } & \multicolumn{4}{|c|}{$\begin{array}{l}\text { Design effects }^{\mathrm{a}} \\
\text { Time of assessment }\end{array}$} \\
\hline & \multicolumn{2}{|c|}{$\begin{array}{l}\text { Beginning of education } \\
\left(1^{\text {st }} \text { semester, } \mathrm{N}=402\right)\end{array}$} & \multicolumn{2}{|c|}{$\begin{array}{c}\text { End of education } \\
\left(6^{\text {th }} 7^{\text {th }} \text { semester, } N=402\right)\end{array}$} \\
\hline & $\begin{array}{l}\text { Subjective } \\
\text { theories }\end{array}$ & $\begin{array}{c}\text { Objective } \\
\text { theories }\end{array}$ & $\begin{array}{l}\text { Subjective } \\
\text { theories }\end{array}$ & $\begin{array}{c}\text { Objective } \\
\text { theories }\end{array}$ \\
\hline Vocational School $(\mathrm{N}=378)$ & 1.81 & 1.83 & 2.28 & 2.39 \\
\hline University (BA-level; N = (417) & 1.06 & 1.21 & 2.53 & 3.17 \\
\hline
\end{tabular}

${ }^{a}$ Design effects are calculated according to the formula: $1+$ (average cluster size -1$) \mathrm{x}$ intraclass correlation.

As can be seen from table 7, all design effects for the graduates are substantial (>2). Therefore, differences between concrete institutions within the university-track and within the track of vocational schools exist. The largest design 
effect occurred between universities. This may be due to the different profiles of bachelor study courses at universities. In contrast, design effects within each track at the beginning of education were not substantial $(<2)$. These results support the interpretation that different profiles (in study courses) increase the variability in cognitive orientations between members of concrete institutions within each track. Thus, is seems less the type of institution (tracks) but the concrete profile of an institution which affects the development of knowledge orientations.

\section{Discussion}

To begin with, students' cognitive orientations could be measured in a reliable manner. The variable centered approach applied to beginners' and graduates' data in this study supports results from a person centered approach applied to data from the "middle" of early childhood education (fourth semester) of Mischo Wahl, Strohmer \& Hendler (2012). The two orientations differentiated in this study were negatively correlated. The absolute value of the negative correlation indicates that these two orientations are not just opposite poles of one construct but two distinct orientations.

Students' scientific orientation increases and subjective orientation decreases during early childhood teacher education. Mean values of the scales were between 2 and 3 (for subjective orientation) and about 3 and above for scientific orientation (on a 4 point rating-scale). From a point of professionalization this result seems desirable because students should not completely give up their orientation towards intuition, personal experience and subjective theories, but noticeably consider scientific theories, concepts and empirical results. In so far, prospective early childhood teachers are somewhat "between" a scientific and a clinical orientation as proposed by Katz (1993) and show a profile which is alike the profile of teacher educators as presumed by Katz.

The change in cognitive orientation might be due to an effect of age and/or an effect of teacher education. Additional analyses show that for all beginners $(\mathrm{N}=956)$, both cognitive orientations were negatively correlated with age (for subjective orientations: $\mathrm{r}=-.23, p<.001$, for objective orientations, $\mathrm{r}=-.22 p<.001$ ), which might indicate that change occurs as a function of age. However, students' scientific orientation slightly more increases in the university track, which might indicate that education track plays a certain (but minor) role in fostering the scientific orientation. The interpretation that teacher education in general fosters a scientific orientation is supported by the increasing variability in cognitive orientations between concrete institutions from the beginning to the end of early childhood teacher education. Hence, the change in cognitive orientation might to a certain degree be a function of age, but probably is also a function of the thematic profile of a concrete institution. Other studies show that learning environments in higher education affect the development of personal epistemologies (Brownlee, Purdie \& Boulton-Lewis, 2001; Tolhurst, 2007). Further studies should address to the thematic profiles of institutions and their impact on the development of orientation quality of prospective early childhood teachers.

Rather than education track a selection bias at the beginning of teacher education contributes most to differences between education tracks: at the beginning of their first semester, prospective teachers with a scientific orientation were attracted by universities, students with a higher subjective orientation were overrepresented in vocational schools. Hence, it can be questioned whether one of the aims of academization of early childhood teacher education in Germany, namely the fostering of a scientific orientation (OECD, 2004; see also the qualifications framework, section 1.4.), can be reached as a result of attending BA courses in early childhood education. In fact data support the view that the overrepresentation of BA students with higher scientific orientations is a due to self-selection as predicted by theories of person environment-fit (Kristof-Brown \& Guay, 2011).

However, the limitations of the present study have to be taken into account. The results reported in this study were based on data of matched pairs which should ensure the comparability of the beginners' and the graduates' cohorts. Though this procedure is a suitable approximation, it cannot substitute an extensive follow up-study covering the whole period of teacher education.

Another limitation lies in the fact that the relation between cognitive orientations and professional action remains unclear. Further studies, which also incorporate in-depth and qualitative analyses as well as observational studies should shed light on the cognitive orientations not only of prospective but also employed early childhood teachers, the relationships between cognitive orientations and professional development, and between curricular profiles of early childhood teacher education and development of cognitive orientations. The probable selection bias at the beginning of teacher education might relativize the effect of different education tracks and draws attention to the question of recruitment of prospective early childhood teachers.

Considering results but also limitations of this study, it seems worthwhile to further investigate the relevance of cognitive orientations in teacher education and professional development of early childhood teachers. 


\section{References}

Belenky, M. F., Clinchy, B. M., Goldberger, N. R., \& Tarule, J. M. (1986). Women's ways of knowing. New York: Basic Books.

Biggs, J. B. (1993). From theory to practice: a cognitive systems approach. Higher Education Research and Development, 12, 73-85. http://dx.doi.org/10.1080/0729436930120107

Black, A. L., \& Halliwell, G. (2000). Accessing practical knowledge: how? why? Teaching and Teacher Education, 16, 103-115. http://dx.doi.org/10.1016/S0742-051X(99)00045-1

Bredekamp, S. (1995). What do early childhood professional need to know and be able to do? Young Children, $50,67-69$.

Bredekamp, S. (Ed.) (1988). Developmentally appropriate practice in early childhood programs serving children from birth through age 8. Washington, DC: National Association for the Education of Young Children.

Brownlee, J., Purdie, N., \& Boulton-Lewis, G. (2001). Changing epistemological beliefs in pre-service teacher education students. Teaching in Higher Education, 6(2), 248-268. http://dx.doi.org/10.1080/13562510120045221

Bosch-Stiftung. (2008). Frühpädagogik studieren - ein Orientierungsrahmen für Hochschulen. [Studying early childhood pedagogy - a qualifications framework for universities]. Retrieved july 2012, from http://www.bosch-stiftung.de/ content/language $1 / \mathrm{html} / 32491$.asp.

Brownlee, J., \& Berthelsen, D. (2006). Personal epistemology and relational pedagogy in early childhood teacher education programs. Early Years: An International Journal of Research, 26, 17-29. http://dx.doi.org/10.1080/09575140500507785

Bryk, A. S., \& Raudenbush, S. W. (1992). Hierarchical linear models. Applications and data analysis methods. Newbury Park, CA: Sage Publications.

Buchmann, M. (1984). The use of research knowledge in teacher education and teaching. American Journal of Education, 92, 421-439. http://dx.doi.org/10.1086/443768

Buehl, M. M., \& Alexander, P. (2001). Beliefs about academic knowledge. Educational Psychology Review, 13, 385-418. http://dx.doi.org/10.1023/A:1011917914756

Buysse, V., \& Wesley, P. W. (2006). Evidence-based practice: How did it emerge and what does it really mean for the early childhood field? Zero to Three, 27, 50-55.

Buysse, V., Wesley, P. W., Snyder, P., \& Winton, P. (2006). Evidence-based practice: What does it mean for the early childhood field? Young Exceptional Children, 9, 2-10. http://dx.doi.org/10.1177/109625060600900401

Buysse, V., Winton, P. J., Rous, B., \& Epstein, D. J., \& Lim, C.-I. (2012). Evidence based practice. Zero to Three, 32, 25-29.

Cervero, R. M. (1990). The importance of practical knowledge and implications for continuing education. Journal of Continuing Education in the Health Professions, 10, 85-94. http://dx.doi.org/10.1002/chp.4750100111

Dweck, C. S., Chiu, C. Y., \& Hong, Y. Y. (1995). Implicit theories and their role in judgments and reactions: A world from two perspectives. Psychological Inquiry, 6, 285. http://dx.doi.org/10.1207/s15327965pli0604_1

Early, D., Maxwell, K., Burchinal, M., Bender, R., Ebanks, C., \& Henry, G. (2007). Teachers' education, classroom quality, and young children's academic skills: Results from seven studies of preschool program. Child Development, 78(2), 558-580. http://dx.doi.org/10.1111/j.1467-8624.2007.01014.x

Fenstermacher, G. D. (1994). The knower and the known: The nature of knowledge in research on teaching. In L. Darling-Hammond (Ed.), Review of Research in Education, Vol. 20 (pp. 3-56). Washington, D.C.: American Educational Research Association.

Freidson, E. (1970). Profession of medicine. A study of the sociology of applied knowledge. New York: Harper \& Row.

Garbett, D. (2003). Science education in early childhood teacher education: Putting forward a case to enhance student teachers' confidence and competence. Research in Science Education, 33, 467-481. http://dx.doi.org/10.1023/B:RISE.0000005251.20085.62

Glaser, R., \& Takanishi, R. (1986). Creating a knowledge base for education: Psychology's contributions and 
prospects. American Psychologist, 41, 1025-1028. http://dx.doi.org/10.1037//0003-066X.41.10.1025

Green, L. W. (2008). Making research relevant: If it is an evidence- based practice, where's the practice-based evidence? Family Practice, 25, 20-24. http://dx.doi.org/10.1093/fampra/cmn055

Groeben, N. (1990). Subjective theories and the explanation of human action. In G. R. Semin, G.R., \& G. Gergen (eds.), Everyday understanding: social and scientific implications (pp. 19-44). London: Sage Publications.

Groeben, N., Wahl, D., Schlee, J., \& Scheele, B. (1988). Das Forschungsprogramm Subjektive Theorien. [The research program subjective theories]. Tübingen: Francke.

Hammersley, M. (2005). The myth of research-based practice: The critical case of educational inquiry. International Journal of Social Research Methodology, 8(4), 317-330. http://dx.doi.org/10.1080/1364557042000232844

Hansen, B. B., \& Bowers, J. (2008). Covariate balance in simple, stratified and clustered comparative studies. Statistical Science, 23, 219-236. http://dx.doi.org/10.1214/08-STS254

Hedges, H. (2012). Teachers' funds of knowledge: a challenge to evidence-based practice. Teachers and Teaching: Theory and Practice, 18(1), 7-24. http://dx.doi.org/10.1080/13540602.2011.622548

Hiebert, J., Gallimore, R., \& Stigler, J. (2002). A knowledge base for the teaching profession: What would it look like and how can we get one? Educational Researcher, 31, 3-15. http://dx.doi.org/10.3102/0013189X031005003

Hofer, B. K. (2001). Personal epistemology research: Implications for learning and teaching. Journal of Educational Psychology Review, 13, 353-383. http://dx.doi.org/10.1023/A:1011965830686

Hofer, B. K., \& Pintrich, P. R. (1997). The development of epistemological theories: Beliefs about knowledge and knowing and their relation to learning. Review of Educational Research, 67, 88-140. http://dx.doi.org/10.3102/00346543067001088

Hughes, J. N., Chen, Q., Thoemmes, F., \& Kwok, O. (2010). An investigation of the relationship between retention in frist grade and performance on high stake tests in third grade. Education Evaluation and Policy Analysis, 32, 166-182. http://dx.doi.org/10.3102/0162373710367682

Hyson, M., Tomlinson, H. B., \& Morris, C. A. S. (2009). Quality improvement in early childhood teacher education faculty perspectives and recommendations for the future. Early Childhood Research and Practice, 11 (1). Retrieved may 2011, from http://ecrp.uiuc.edu/v11n1/hyson.html

Iacus, S. M., King, G., \& Porro, G. (2011). Causal inference without balance checking: Coarsened exact matching. Political Analysis, 20, 1-24. http://dx.doi.org/10.1093/pan/mpr013

Kallery, M. (2001). Early-years educators' attitudes to science and pseudo-science: the case of astronomy and

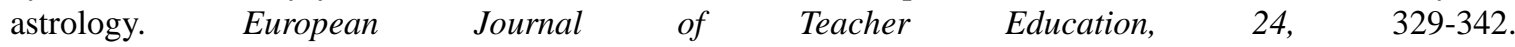
http://dx.doi.org/10.1080/02619760220128888

Katz, L. G. (1987). The nature of professions: Where is early childhood education? In L. Katz (Ed.), Current topics on early childhood education (Vol 7, pp. 1-17.). New Jersey: Ablex Publishing Corporation.

Katz, L. G. (1993). Trends and issues in the dissemination of child development and early education knowledge. International Journal of Early Years Education, 1, 7-17. http://dx.doi.org/10.1080/0966976930010202

Kelley, P., \& Camilli, G. (2007). The impact of teacher education on outcomes in center-based early childhood education programs: A meta-analysis. Retrieved November 2010, from http://nieer.org/resources/research/TeacherEd.pdf

Kinos, J., \& Virtanen, J. (2008). The fourth science of education. Early childhood education as a discipline in the curricula of Finnish universities. Nordic Early Childhood Education Research, 1, 3-15.

Kristof-Brown, A. L., \& Guay, R. P. (2011). Person-environment fit. In S. Zedeck (Ed.), APA handbook of industrial and organizational psychology Vol. 3. (pp. 3-50). Washington, DC: American Psychological Association.

Latta, M. M., Buck, G., Leslie-Pelecky, D., \& Carpenter, L. (2007). Terms of inquiry. Teachers and Teaching: Theory and Practice, 13(1), 21 - 41. http://dx.doi.org/10.1080/13540600601106047

Laursen, B., \& Hoff, E. (2006). Person-centered and variable-centered approaches to longitudinal data. Merill Palmer Quarterly, 52, 377-389. http://dx.doi.org/10.1353/mpq.2006.0029 
Lodewyk, K. R. (2007). Relations among epistemological beliefs, academic achievement, and task performance in secondary school students. Educational Psychology, 27, 307-327. http://dx.doi.org/10.1080/01443410601104080

Loughran, J., Mitchell, I., \& Mitchell, J. (2003). Attempting to document teachers' professional knowledge. International Journal of Qualitative Studies in Education, 16(6), 853-873. http://dx.doi.org/10.1080/09518390310001632180

Mischo, C., Wahl, S., Hendler, J., \& Strohmer, J. (2012). Warum in einer Kindertagesstätte arbeiten? Entscheidungstypen und Ausbildungs-/Studienmotivation bei angehenden frühpädagogischen Fachkräften an Fachschulen und Hochschulen. [Why work in a kindergarten? Types of decision and study motivation of prospective early childhood teachers in Germany]. German Journal of Educational Psychology, 26(3), 167-181. http://dx.doi.org/10.1024/1010-0652/a000072

Mischo, C., Wahl, S., Strohmer, J., \& Hendler, J. (2012). Knowledge orientations of prospective early childhood teachers. Journal of Early Childhood Teacher Education, 33, 144-162. http://dx.doi.org/10.1080/10901027.2012.675836

Morgan, G. G. (2003). Staffing. In D. Cryer, D., \& R. M. Clifford (eds.), Childhood Education and Care in the USA (pp. 58-72). Baltimore: Brookes Publishing.

Muthén, L. (2010). Personal note in Mplus Discussion group. Retrieved july 2012, from http://www.statmodel.com/discussion/messages/12/18.html.

National Association for the Education of Young Children NAEYC and National Association of Child Care Resource \& Referral Agencies NACCRRA. (2011). Early childhood education professional development: Training and technical assistance glossary. Retrieved may 2011, from http://www.naeyc.org/files/naeyc/file/ ecprofessional/ NAEYC_NACCRRA_TrainingTAGlossary.pdf.

National Registry of Evidence-Based Practices and Programs NREEP. (2007). NREPP Review Criteria. Retrieved march 2008, from http://www.nrepp.samsha.gov/review-criteria.htm.

NICHD Early Child Care Research Network. (2002). Child-care structure - process - outcome: Direct and indirect effects of child care quality on young children's development. Psychological Science, 13, 199-206. http://dx.doi.org/10.1111/1467-9280.00438

NICHD Early Child Care Research Network. (2003). Does quality of child care affect child outcomes at age 4 1/2? Developmental Psychology, 39, 451-469. http://dx.doi.org/10.1037/0012-1649.39.3.451

OECD. (2004). Die Politik der frühkindlichen Betreuung, Bildung und Erziehung in der Bundesrepublik Deutschland. Ein Länderbericht der Organisation für wirtschaftliche Zusammenarbeit und Entwicklung (OECD) [The policy of early childhood education and care in Germany].

Oberhuemer, P., Schreyer, I., \& Neuman, M. (2010). Professionals in early childhood education and care systems: European profiles and perspectives. Opladen \& Farmington Hills, MI: Barbara Budrich.

Pajares, F. (1992). Teachers' beliefs and education research: Cleaning up a messy construct. Review of Educational Research, 62, 307-332. http://dx.doi.org/10.3102/00346543062003307

Penn, H., \& Lloyd, E. (2007). Richness or rigour? A discussion of systematic reviews and evidence-based policy in early childhood. Contemporary Issues in Early Childhood, 8(1), 3-18. http://dx.doi.org/10.2304/ciec.2007.8.1.3

Perry, W. G. (1970). Forms of intellectual and ethical development in the college years: a scheme. New York: Holt, Rinehart \& Winston.

Pianta, R., Howes, C., Burchinal, M., Bryant, D., Clifford, R., Early, D., \& Barbarin, O. (2005). Features of pre-kindergarten programs, classrooms, and teachers: Do they predict observed classroom quality and child-teacher interactions? Applied Developmental Science, 9, 144-159. http://dx.doi.org/10.1207/s1532480xads0903_2

Rodriguez, L., \& Cano, R. (2006). The epistemological beliefs, learning approaches and study orchestrations of university students. Studies in Higher Education, 31, 617-636. http://dx.doi.org/10.1080/03075070600923442

Rosenbaum, P. R., \& Rubin, D. B. (1983). The central role of the propensity score in observational studies for causal effects. Biometrika, 70, 41-55. http://dx.doi.org/10.2307/2335942

Russell, T. L. (1987). Research, practical knowledge, and the conduct of teacher education. Educational Theory, 37, 369-375. http://dx.doi.org/10.1111/j.1741-5446.1987.00369.x 
Saracho, O. N., \& Spodek, B. (2007). Early childhood teachers' preparation and the quality of program outcomes. Early Child Development and Care, 177(1), 77-91. http://dx.doi.org/10.1080/03004430500317366

Schmid, S., \& Lutz, A. (2007). Epistemological belief as coherent lay theories. German Journal of Educational Psychology, 21, 29-40. http://dx.doi.org/10.1024/1010-0652.21.1.29

Schommer, M. (1990). Effects of beliefs about the nature of knowledge on comprehension. Journal of Educational Psychology, 82, 498-504. http://dx.doi.org/10.1037//0022-0663.82.3.498

Schommer, M. (1994). Synthesizing epistemological belief research: Tentative understandings and provocative confusions. Educational Psychology Review, 6, 293-319. http://dx.doi.org/10.1007/BF02213418

Schommer-Aikens, M. (2004). Explaining the epistemological beliefs system: introducing the embedded systemic model and co-ordinated research approach. Educational Psychologist, 39, 19-29. http://dx.doi.org/10.1207/s15326985ep3901_3

Shulman, L. S. (1986). Those who understand: Knowledge growth in teaching. Educational Researcher, 15, 4-14. http://dx.doi.org/10.3102/0013189X015002004

Silin, J. G. (1987). The early childhood educator's knowledge base: A reconsideration. In L. G. Katz (Ed.), Current topics in early childhood education, Vol. 7 (pp. 17-31). Norwood, NJ: Ablex.

Snider, J. H., \& Fu, V. R. (1990). The effects of specialized education and job experience on early childhood teachers' knowledge. Early Childhood Research Quarterly, 5, 69-78. http://dx.doi.org/10.1016/0885-2006(90)90007-N

Spodek, B. (1987). Thought processes underlying preschool teachers' classroom decisions. Early Child Development and Care, 29, 197-208. http://dx.doi.org/10.1080/0300443870290207

Stuart, E. A. (2010). Matching methods for causal inference: A review and a look forward. Statistical Science, 25, 1-21. http://dx.doi.org/10.1214/09-STS313

Tobin, J. (2007). An anthropologist's reflections on defining quality in education research. International Journal of Research and Method in Education, 30(3), 325-338. http://dx.doi.org/10.1080/17437270701614816

Tolhurst, D. (2007). The effect of learning environments on students' epistemological beliefs and learning outcomes. Teaching in Higher Education, 12(2), 219-233. http://dx.doi.org/10.1080/13562510701191992

Thomas, G. (2004). Introduction: Evidence and practice. In G. Thomas \& R. Pring (Eds.), Evidence-based practice in education (pp. 1-18). Buckingham: Open University Press.

Tracz, S. M., Nelson, L. L., Newman, I., \& Beltran, A. (2005). The misuse of ANCOVA: The academic and political implications of Type VI erros in studies of achievement and socioeconomic status. Multiple Linear Regression Viewpoints, 31, 19-24.

Vartuli, S. (1999). How early childhood teacher beliefs vary across grade level. Early Childhood Research Quarterly, 14, 489-514. http://dx.doi.org/10.1016/S0885-2006(99)00026-5

Vartuli, S., \& Rohs, S. (2009). Early childhood prospective teacher pedagogical belief shifts over time. Journal of Early Childhood Teacher Education, 30, 310-327. http://dx.doi.org/10.1080/10901020903320262

Walker, S., Brownlee, J., Whiteford, C., Exely, B., \& Woods, A. (2012). A Longitudinal Study of Change in Preservice Teachers' Personal Epistemologies. Australian Journal of Teacher Education, 37(5), 24-35.

Wang, M. C., Haertel, G. D., \& Walberg, H. J. (1993). Toward a Knowledge Base: Why, How, for Whom? Review of Educational Research, 63(3), 365-376. http://dx.doi.org/10.3102/00346543063003365

Whitebook, M. (2003). Early education quality: Higher teacher qualifications for better learning environments A review of the literature. Summary Version. Retrieved november 2008, from http://www.iir.berkeley.edu/cscce/pdf/teacher.pdf.

Yost, D. S., Sentner, S. M., \& Forelnaz-Bailey, A. (2000). An examination of the construct of critical reflection: Implications for teacher education programming in the 21st century. Journal of Teacher Education, 51, 39-49. http://dx.doi.org/10.1177/002248710005100105

Zaslow, M., Tout, K., Halle, T., Wittaker, J. E., \& Lavelle, B. (2010). Emerging Research on Early Childhood Professional Development. In S. Neumann \& M. Kamil (Eds.), Preparing teachers for the early childhood classroom (pp. 17-47). Baltimore: Paul H. Brookes Publishing.

\section{$(\mathrm{cc}) \mathbf{E Y}$}

This work is licensed under a Creative Commons Attribution 3.0 License. 